\title{
GH1 Gene
}

National Cancer Institute

\section{Source}

National Cancer Institute. GH1 Gene. NCI Thesaurus. Code C30154.

This gene is involved in the control of body growth. It also plays a role in protein synthesis as well as in cell differentiation, growth and proliferation. 